\title{
MIMESIS AND HUMAN GEOGRAPHY IN PAUL VIDAL DE LA BLACHE'S METHOD
}

https://doi.org/10.4215/rm2020.e19029

\section{Guilherme Ribeiro ${ }^{*}$}

(a) PhD in Geography. Professor at the Federal Rural University of Rio de Janeiro (UFRRJ), Seropédica (RJ), Brazil.

ORCID: https://orcid.org/0000-0002-5564-8619. LATTES: http://lattes.cnpq.br/7817656334196950.

Article history:

Received 19 September, 2020

Accepted 25 September, 2020

Publisher 15 December, 2020
(*) CORRESPONDING AUTHOR

Address: BR 465, KM 47, Seropédica, Rio de Janeiro. CEP: 23890-000. Phone: (+55 21) 972959674

E-mail: lapeghe@gmail.com

\begin{abstract}
Based on the concept of mimesis elaborated by the Brazilian literature theorist Luiz Costa Lima Brazilian scholar, this article aims to analyse the Vidalian human geography. Its particular use of description and its capacity of metamorphosing environmental elements into geographical categories able to revealing the French national identity under the long-run time show how complex and relevant its method is.
\end{abstract}

Keywords: Vidal de la Blache, Human Geography, Mimesis, Environment, Geographical Method.

\section{Resumo / Résumé}

\section{MÍMESIS E GEOGRAFIA HUMANA NO MÉTODO DE PAUL VIDAL DE LA BLACHE}

o presente artigo visa a analisar a geografia humana vidaliana a partir do conceito de mímesis elaborado pelo teórico da literatura Luiz Costa Lima Seu emprego peculiar da descrição e sua capacidade de metamorfosear elementos do meio ambiente em categorias geográficas reveladoras da identidade nacional francesa em uma escala história multissecular nos levam a concluir pela complexidade e pela importância de seu método.

Palavras-chave: Vidal de la Blache, Geografia Humana, Mímesis, Meio, Método Geográfico.

MÍMESIS ET GÉOGRAPHIE HUMAINE DANS LA MÉTHODE DE PAUL VIDAL DE LA BLACHE

A partir du concept de mimesis élaboré par le théorique de la littérature Luiz Costa Lima, cet article vise à analyser la géographie humaine vidalienne. Son usage particulier de la description et sa capacité de métamorphoser des éléments du milieu en catégories géographiques révélatrices de l'identité nationale française dans la longue durée soulignent l'importance et la complexité de sa démarche

Mots-clés: Vidal de la Blache, Géographie Humaine, Mimesis, Milieu, Méthode Géographique. 


\section{INTRODUCTION}

A thematic affinity has attracted part of our generation to the history and epistemology of the geography formed at the beginning of the last century; however, they were probably also dissatisfied with the hegemonic interpretations available in Portuguese. In the late 1990s and early 2000s, each reading of a text authored by Paul Vidal de la Blache, Friedrich Ratzel, or Halford John Mackinder confirmed that our intuition was on the right track: their writings had little or nothing to do with what we were learning under the label of "traditional" geography. Although it is counterproductive to attest to the frequent derogatory use of the term in the most diverse sources, it is of enormous value to continue to recover and problematize the legacy of the geographical "classics." Besides the objective question of doing justice to their pioneering spirit on several fronts, ultimately, examining Brazilian production over the last two decades, including translations, enables us to reflect more appropriately on the history of geography's role in the training of future geographers. Unfortunately, at the time of writing (2020), this field is still perceived as a mere luxury or exotic accessory or less relevant than spheres like urban or economic geography. A rapid survey of the distribution of grants by funding agencies may confirm this preference. This disdain has several consequences, especially a superficial knowledge of geography's general trajectory and the classics' relegation to a past to which today's doors are firmly closed. There are other facets to this diagnosis, which will be the subject of further studies. For now, some of the lessons learned need to be called into question.

Although the present article focuses on Paul Vidal de la Blache, his unconscious roots lie in another "classic" geographer. As the British scholar Mackinder was principally canonized for his geopolitical reflections, it was even more astonishing to discover the analytical scope and stylistic elegance of The teaching of geography from an imperial point of view, and the use which could and should be made of visual instruction (1911). As they merge objective and subjective aspects, maps are a central pedagogical tool in geographic education, aiding the complicated process of understanding and articulating phenomena, a vital requirement in the case of the truly global British empire. However, these are not technical explanations and ready-made formulas about subtitles and coordinates. Mackinder invites the imagination to go beyond using history and literature as pragmatic auxiliary sciences and instead consider them as languages. Temporal flow and textual narrative inspire and illuminate geographic form and the visualization of the "wordless language" represented by maps.

\footnotetext{
The real geographer prefers a map without names. He broods over it by the hour together, for it is rich in suggestion. He sees the world-drama as he reads his morning paper. He gesticulates unconsciously as he thinks. Within limits his wordless language has great resource, for whereas in ordinary talk we can make only one statement at a time, many thousand statements are made simultaneously on a map. The trained geographer, when he considers a fact, sees it on a background of kindred facts. In other words, he sees it in the perspective of space, just as it is characteristic of the historian that he sees each occurrence in the perspective of time (MACKINDER 2014: 145 [1911]).
}

In the throes of the Second World War, Mackinder reworked some of these theses and, through the interlocution of Plato, Socrates and Aristotle, took a step forward by proposing that geography is both a philosophy of the Earth's surface thanks to its comprehensive and articulated apprehension of phenomena1 and a "visual way of thinking" (MACKINDER 1942: 122). Its role complements literature: if the former develops its plots through words, geography notably does so through images, $\quad$ in "an independent Art of Expression" (idem, pp. 129 and 125).

To mention another example en passant, the direct translations of Ratzel's work from the original German, digitized in the Nossos Clássicos section of the Geographia Jornal (UFF)3, offer us the opportunity to rediscover an intellectual dedicated to associating art and science, aesthetics and analysis, fruition and rigor. Amid a tradition centered on von Humboldt and his studies with Goethe, in On the interpretation of Nature (Über die Natürschilderung), Ratzel validates geographical description as a sophisticated act of landscape painting and also states that "Nature has not always revealed the essence of a phenomenon on the surface, but true artists have frequently sensed it long before researchers and thinkers. There are many cases in which art has anticipated science in the correct understanding of a natural phenomenon" (RATZEL 2010: 167 [1904]). His conclusion bothers determinists because he 
believes that "Science is not enough to understand the language of nature" (idem, p.157).

This rapid mention of Mackinder and Ratzel is pertinent because there has only been a single translation into Portuguese of the British scholar's work in the last century (MACKINDER 1943 [1954]); it is not, therefore, an exaggeration to consider him an illustrious unknown to most of our national geographic community. As for Ratzel, his thinking has been the subject of considerable distortion. Although already old, unfortunately, the bibliography dedicated to reversing this situation has not yet reached us satisfactorily (BASSIN 1987, 1987a, 1987b; SMITH 1991; RAFFESTIN, LOPRENO \& PASTEUR 1995) and even pioneering articles written in Portuguese have not had the expected impact ( CARVALHO 1997, 1997a).

From the heritage of Ibn Battuta to the neopositivists, and later the radicals, there is enough material to justify a re-reading of "classical" geography. We insist on the use of quotation marks to indicate the precariousness of such classifications. Suppose both schools of thought had particular political and epistemological reasons to criticize the "classical" period eloquently.

In that case, in the twenty-first century, it might be time to explore new analytical tools if we want to refresh our learning of those authors to whom labels like descriptivism, empiricism, possibilism, determinism, positivism, and objectivism have been applied, in a manner that reveals above all the fragility of those who ascribed them.

Just as an illustration, in his approach to spatial science Alan Pred confesses that his involvement with the work of authors like Christaller and the chance to do something new led him to translate Torsten Hägestrand's famous Innovation Diffusion as a Spatial Process from Swedish to English in 1967, however, he had never read authors like Vidal de la Blache (PRED 1984). The discomfort generated by the failure to read the classics is not recent (MARTIN 2005 [1972]); nevertheless, in recent years, the history of geography has been the object of the renewed interest of professionals from different places and traditions.

From "decanonization" to "decolonization" (KEIGHREN, ABRAHAMSSON \& DELLA DORA 2012; RIBEIRO, HAESBAERT \& PEREIRA 2012; MELGAÇO 2017; FERRETTI 2019; DAVIES 2019), they are united by the awareness of extracting the classics' plurality, to reinterpret them critically and to bring them to the present, either to clarify empirical phenomena or to enrich the epistemological repertoire. Furthermore, it is imperative to rethink modernity's force lines and displace Europe as the world's center4. Although it was not always evident, in our case, decolonial philosophy had a significant influence, mostly thanks to the Argentine Walter Mignolo and his concepts of territorial epistemology, the geopolitics of knowledge, epistemic disobedience, and decolonial translation (MIGNOLO 2003 [2000], 2009, 2012).

The concept of mimesis, as perceived by the Brazilian Luiz Costa Lima, has inspired us, an option that avoids a dose of rationalism alcoholic enough to be abandoned. In particular, his rejection of the consecrated definitions of fiction and literature, the effects of fictional discourse across different historical periods, and the complex articulations involving the role of "reality" in creating and understanding literature (COSTA LIMA 1997, 2000, 2006, 2018).

The subsequent pages promote a reinterpretation of Vidalian human geography, emphasizing that his method went far beyond empirical descriptions of the phenomena visible in the landscape, that human-nature relationships appealed to the subjectivity of objective elements of the soil and environment, and that the construction of nationalism essentially involved the historical-political mobilization of the territory.

This article has four parts: the first provides a reading framework that asserts the complementarity and not the separation between the modern academic concepts of geopolitics, political geography, and geography. The dimension of mimetics is added to this perspective.

The second section aims to illuminate the epistemological novelty represented by the emergence of Ratzel and Vidal de la Blache's human geography, linked, however, to the latter's political-imperial composition. Next, we examine texts by Vidal de la Blache, which characterize a genre of geographical mimesis. Finally, we highlight the manuscript's central parts, emphasizing the scope of using mimesis to comprehend the Vidalian geographic method. 


\section{GEOPOLITICS, POLITICAL GEOGRAPHY, AND GEOGRAPHY: MIMETIC CONCEPTS?}

According to Michel Foucault, the emergence of a field of knowledge both an intellectual and a political issue (FOUCAULT 1971 [1970]). For example, this is evident in geopolitics, as the word itself denounces its intentions. However, if the emergence of this concept dates from the end of the nineteenth century in Europe, covering conflicts and agreements between nation-states on a world scale, there is an evident "epistemological gap" between it and the ancient practices of spatial control and organization since the Roman Empire.

Likewise, although the expression did not yet exist, how many words are as appropriate as geopolitics to illuminate the Atlantic Revolution, the conquest of America, and the birth of Modernity? Perhaps this absence partly explains why Carl Schmitt used the Greek concept nomos in his masterpiece The Nomos of the Earth in the International Law of the Jus Publicum Europaeum (SCHMITT 2014 [1950]) to show how a particular definition of space, directly associated with land tenure and ownership, is inseparable from the western modus operandi as a whole. Consequently, zones and boundaries, territories, and borders are not just part of geopolitical discourse; they are also intimately linked to the fundamental Western instances of law, sovereignty, and State.

In this context, the history of geopolitics is like a dance of light and shadow. Ratzel is considered one of the founders of this approach; during the German State's unification, he adopted the term Politische Geographie, which was also the title of his book on the topic in 1897. His groundbreaking tome is the first systematization by a geographer of the political dimension of space, territory, borders, and land (RATZEL 1987 [1897]). Two years later, inspired by Ratzel, the Swedish Germanophile Rudolf Kjéllen pioneered the term geopolitics (Kjéllen 1899 apud HOLDAR 1992). However, the most famous article on this topic, Mackinder's The geographical pivot of history (1904), solemnly ignored the novelty (MACKINDER 1904).

In the first half of the twentieth century, when geopolitics became a synonym for Nazism-Fascism, it came under intense attack from French and American intellectuals such as Lucien Febvre, Albert Demangeon, and Isaiah Bowman, with the latter two suggesting a Manichean distinction between political geography and geopolitics5 (FEBVRE 1922; DEMANGEON 1932, 1939; BOWMAN 1942). Both erroneous and successful, these attacks had at least three effects: the political "purification" of Vidal de la Blache, the impoverishment of the Ratzelian legacy, and the concealment of the eloquent geopolitical and imperialist content present in the writings of the intellectuals mentioned above. Continuing to apply the Foucaultian approach to this problem, it is evident that understanding science means considering a range of elements that were suspended or excluded in a given historical period and not just those that were incorporated and enshrined. Thus, all the definitions that establish a canonical definition of geopolitics should be considered suspect (FOUCAULT 1971 [1970]; Ó TUATHAIL 1996, 1998).

Similar reasoning can be applied to the academic concept of geography. Commonly interpreted as the relationship between humans and the environment, this definition omits the political, economic, and ideological constituents of a science whose academic autonomy occurred precisely during the Age of Empires (1875-1914) and the advent of nationalism (HOBSBAWM 1987). In the name of the smokescreen of scientific neutrality, from Augusto Comte to Max Weber, activities such as fieldwork, landscape descriptions, and regional mapping were normalized as geographers' métier par excellence, as if it were possible to separate them from their colonialist ambitions. For this reason, we make the point that despite the specificities of their scale and methods, the concepts of geopolitics, political geography, and geography must be examined from the perspective of complementarity.

In the service of the formation of the Nation-State, capitalist competition, and the imperialist race, these concepts were mobilized as part of a spatial crisis triggered by the European Empires at the time of the Franco-Prussian War and culminated in the two world wars (see, again, SCHMITT 2014 [1950]). As different sides of the same coin, national and international issues merged through the concepts above. Thus, the validation of an external danger can only occur if a prior sense of territorial ownership has already been forged. Likewise, an "overseas" colony thousands of kilometers from Europe will only be appropriated as "ours" if soldiers, missionaries, teachers, and public opinion are convinced that they 
belong to an "imagined community" (ANDERSON 1983). At the same time, external threats act to mask national contradictions (COWEN \& SMITH 2009).

From a methodological standpoint, it may be possible to organize the issue as follows: geography, political and geopolitical geography have undergone a kind of "mimesis" which, according to the Brazilian Luiz Costa Lima, cannot be reduced to the notion of imitation (see also BLUMENBERG 2010 [1957]). Costa Lima's fertile explorations of the nature of literary discourse and its relationship with the real and his dissatisfaction with the concept of fiction do not adhere to Jacques Derrida's deconstructionism, linguistic twists à la Hayden White, or overvalue the aesthetic (see COSTA LIMA 2010). Indirectly, we are obliged to remember both the condition of the nascent human sciences amid the "paradigm" of natural sciences and literature's role in the nineteenth century. This leads us to the centrality of language and aesthetics in Alexander von Humboldt's analysis of landscapes (LEPENIES 1996 [1985]; HUMBOLDT 2010 [1827-1828]; WULF 2016 [2015]).

\begin{abstract}
In general, we can say that mimesis presupposes a correspondence between a first, guiding and general scene, and a second scene, particularized in a given work, which finds therein the parameters that enable its recognition and acceptance. However, the ease with which this statement is formulated is quickly complicated by the clarifications required. From the outright, Michael Taussig's product is a "copy that is not a copy," because in it, "the similarity is not in itself enough," Therefore, when we speak of a "guiding scene," we differentiate it from a model scene. If mimesis supposed a model scene or, more simply, a model, we would be admitting that it has a normative character. On the contrary, what is fundamental in the phenomenon of mimesis is the correspondence established between a particular work - the second scene - and parameters that guide the receiver (COSTA LIMA 2000: 22).
\end{abstract}

Transfering this reasoning to geography, we argue that geographic mimesis, as we interpret it, is the antithesis of the dichotomous determinist-possibilist Febvrian model and the puerile view of geography as an empirical and immobile scenario for human action (FEBVRE 1922). On the contrary, it is an intricate design from which places and landscapes become a nation's soul, mountains and rivers represent sacred lands since time immemorial, and citizens have converted themselves into territorial boundaries.

Transcending individuals' time, Nature's lengthy timespan both strengthens the ties between societies and their respective environments and converts physical geography into political and geopolitical geography (we will return to this topic later). In the absence of an adequate term, it may be assumed that this "hybridity" forced geographers to mimitize the Earth's surface, not from the positivist perspective of science as a neutral reflection of reality and the automatic description of nature-copy, but metamorphosing men and environments in landscapes, regions, territories, places, and nations and, at the same time, to reorganize their writing. Costa Lima's observation is pertinent here, "outside of mathematical language, which, however, is not to be confused with dis-covering what it is, every new scientific paradigm presupposes the participation of the fictional without it becoming the dominant layer" (COSTA LIMA 2018: 19-20).

Parenthetically, as far as we are aware, there is a project still pending in the textual comparison between post-Ratzel human geography and preceding geographers as such a study might be able to illuminate some aspects referring to the mimesis mentioned here6 .

Furthermore, it is not by chance that this article opened with Mackinder. Human geography is also based on the visual language required by maps, avant la lettre panoptic instruments blending art and science, a remarkable capacity for synthesis and, above all, the sleight of hand that brings together the far off, making maps one of mimesis' most powerful instruments (see ALPERS 1999 [1983]; COSGROVE 2003; GRATALOUP 2009; BROTTON 2012).

A mix of politics and epistemology, location, and distribution are more than mathematical coordinates; they are ways of classifying areas and people, a spatial taxonomy responsible for the world's hierarchy. In doing so, maps have shaped a plethora of images whose effect is to geographically legitimize modernity's political imaginary (RIBEIRO 2015. See also MIGNOLO 2005; MEZZADRA \& NEILSON 2013). 


\section{THE EPISTEMOLOGICAL EMERGENCE OF HUMAN GEOGRAPHY: A CRITICAL NOTE}

The words determinism and possibilism forged in 1922 by the French historian Lucien Febvre in La terre et l'évolution humaine: introduction géographique à l'histoire (FEBVRE 1922) caused so much confusion about the emergence and nature of human geography that, despite the considerable accumulation of criticisms from different countries and lines of thought (LACOSTE 1988 [1976]; MARTINS 2001; BAKER 2006 [2003]; GÓMEZ MENDOZA 2008 [2007]; RIBEIRO 2009), its effects are still felt a century later. The pages below follow the opposite path to his.

Anthropogeographie and subsequently the Géographie Humaine, were imbued with the old geographic legacies regarding cartographic distribution and the political attempts to delimit space. However, its great innovation lies in the profound transformations caused by humans on the Earth's surface. At the turn of the nineteenth century, recognizing a long-lasting historical process was at stake, including European Maritime-Commercial Expansion, the Industrial Revolution, and Colonialism. These developments submitted the relief, vegetation, hydrography, and distances to human action at an unprecedented scale and speed, altering the perception of space-time and the totality of social life. Historically, geographic elements have always been associated with physical-natural characteristics; however, the development of engineering techniques, steam navigation, the telegraph, submarine cables, and railways brought new forms to the landscape, enshrining humans as different from other living beings. However, according to Fernand Braudel's The structures of everyday life, humankind was still organic and waged a battle against the "Old Biological Regime" that would only end in the eighteenth century. Before that, "the jungle book [could] be opened anywhere. It will be wise to close it before anyone gets lost. But what a testimony to the weaknesses of human occupation!" (BRAUDEL 1996: 58 and 57 [1967]).

It is precisely within this framework that we must accept Ratzel and Vidal de la Blache's arguments on creating human geography. Only then will we understand why they linked it to phytogeography and zoogeography using Darwinism and Neo-Lamarckism as their theoretical sources (RAFFESTIN, LOPRENO \& PASTEUR 1995; BERDOULAY \& SOUBEYRAN 1991; and, most of all, SOUBEYRAN, 1997). After all, like animals and plants, as a geographical factor humans are also inherently subject to the weather, adaptation, and migration in the most diverse environments. Therefore, Ratzel's famous monograph on living space, Lebensraum, is subtitled "a biogeographic study" [ eine biogeographische studie ] (RATZEL 2019 [1901]). The same applies to the introduction of his Anthropogeographie (whose first edition dates from 1882), which was titled The unity of life and biogeography. His first paragraph states plainly that "anthropogeography can only be considered as a branch of biogeography and many biogeographic concepts must certainly apply to the study of the spread of man over the Earth" (RATZEL 1914: 1 [1899 ]). He ends the chapter concluding without hesitation that "Anthropogeography can only have a solid scientific basis when it takes as its cornerstone the general law that governs the diffusion of all organic life on Earth" (idem, p.8).

Two decades later, in the theoretical-methodological article La géographie humaine. Ses rapports avec la géographie de la vie, whose similarity with Anthropogeographie is entirely deliberater, Vidal de la Blache emphasizes that "The conditions that governed the distribution of the human species, the composition of the main groups and their adaptation to different environments are analogous to those revealed by flora and fauna (...) This branch of [human] geography has the same origin as the botanical and zoological geographies. It is from them that they draw their perspective. The method is analogous (...)" (VIDAL DE LA BLACHE 1903: 221 and 224).

The examples above can be extended if we consider, on the one hand, the Ratzelian concept of the State as an organism and, on the other, the naturalization of geographical phenomena found in the two Vidalian texts dedicated to the idea of genre of vie and in the unfortunate statement that geography is the science of places and not of men (RATZEL 1988 [1897]; VIDAL DE LA BLACHE 1911b, 1911c, 1913). The interpretations attesting to Vidal de la Blache as a practitioner of the Ecology of Man (ROBIC 2013: 141 [1993]) and the naturalist status of his geography (RHEIN 1982: 244) are also well known, as is the finding that the French School of geography used an organicist language (BERDOULAY 1988: 75-87) or that, in its classical form, geography was a natural science of society (CLAVAL 2007: 22). 
Despite these scholars' pioneering spirit and rigor, it may be useful to explore the issue from other analytic angles. Although we agree that Ratzel and Vidal de la Blache's views on the formation and agency of society and social groups were embryonic and that they were undeniably disposed to the methods of Natural Sciences, in our judgment, both also had a concrete notion of the social and historical context of their times and the political, economic and territorial conflicts that shaped world history. The late formation of the German State and the consequent delay in its colonial expansion are among the cultural influences that shaped Ratzelian geography. Equally, the preservation of the French Empire and the Franco-Prussian War contributed to the raw material of Vidalian geography. In our view, they are no less significant than Darwinism and Lamarckism. Why, then, value epistemological elements and minimize historical-cultural traits? Why canonize theoretical-methodological texts at the expense of political writings, dichotomizing them? Both author's oeuvres preclude an interpretation focused only on one characteristic or another.

These canonizing traps must be overcome and replaced with interpretations that reposition "classical" geography (we prefer the term "imperial" geographies) as a historical-epistemological formulation to the challenges of modernity, which displaced the longstanding centrality of the rural hierarchy to make way for the urban-industrial dynamics of the age. Just as it is possible to portray Vidal de la Blache with naturalist hues, he can also be depicted as a social, historical, and political author. Therefore, it is plausible to state that the biogeographic reference found in the "canonized" Vidal de la Blache was shaken by urbanization, industrialization, and technical development.

The French scholar's journey to the United States in 1904 showed him the need to modernize French territory, as we infer from A travers l'Amérique du Nord (VIDAL DE LA BLACHE 1905) and Les chemins de fer en Amérique (VIDAL DE LA BLACHE 1912). The new economic dynamics reorganized the previously fixed scale and function of cities and regions, according to the writings Régions françaises (VIDAL DE LA BLACHE 1910), La relativité des divisions régionales (VIDAL DE LA BLACHE 1911), and La rénovation de la vie régionale (VIDAL DE LA BLACHE 1917). The structure in La France de l'Est: Alsace-Lorraine (VIDAL DE LA BLACHE 1994 [1917]) is not based on "natural" regions or borders; instead, he uses social and political arguments in favor of the Hexagon's territorial integrity and economic survival. The French Empire should be alert to its adversaries' movements in the international geopolitical scenario if it wished to maintain its position as the second-largest colonial power. These arguments are expressed in La zone frontière de l'Algérie et du Maroc, d'après de nouveaux documents (VIDAL DE LA BLACHE 1897), La carte internationale du monde au milionième (VIDAL DE LA BLACHE 1910a) and La conquête du Sahara d'après E. F. Gautier (VIDAL DE LA BLACHE 1911a). Therefore we insist: why state only one side of the issue?s

Ultimately, Ratzel and Vidal de la Blache were part of an era of Western geographic awareness marked by the pre-industrial past and a present in which the lines between local and global were rapidly becoming blurred. Hence, their geography does not lack a human element. Plants and animals, weather and climate, the plain and the mountain, proximity to the sea, and the continents' strength were structures that impeded movement. However, techniques, culture, and politics promoted the domestication of plant and animal species, thus creating agriculture. They also built cities and institutions as forms of social coexistence and established National States and Colonial Empires, which surpassed the limits of the Mediterranean and conquered the whole planet in the name of money and power. In their right mind, who would claim that it is impossible to comprehend Politische Geographie and Principes de Géographie Humaine in that light? (RATZEL 1988 [1897]; VIDAL DE LA BLACHE 1954 [1921]).

\section{THE METHOD OF VIDALIAN GÉOGRAPHIE HUMAINE: A GENRE OF MIMESIS?}

9

We begin this section with the Vidalian intention to forge a unifying regional discourse in which peasants and city dwellers, and provinces and departments, were called upon to participate actively in a broad and heterogeneous group called France. This was the scene portrayed at the dawn of the twentieth century in Routes et chemins de l'ancienne France (VIDAL DE LA BLACHE 1996-1997 [1902]. See 
also, ROBIC 1996-97; CLAVAL 2003) when the living spaces of the common man were rescued, underlining the practices that created material and symbolic geographies. Through the pilgrims' sayings, painting, and movement, the nation's cultural-popular face was exalted. There was a single message between the lines: in the transition to urban-industrial modernity, it was essential to recall the legacy of the past since France was built by peasants who skillfully knew how to manage the natural conditions in their locality. Particular attention should be paid to rural communities and their respective pays, whether they were rooted in the hills of the old medieval villages, the mountains occupied by the shepherds, or the water-rich valleys. There was a debt of gratitude to the Auvergne, Gascones, Savoyards, and so many others, mostly isolated, who made France great. Nevertheless, an "extra-human" element should also be celebrated: the territory and its regions, points of immanence that shape the national genius and identity.

Routes et chemins reveals an appreciation for fieldwork and the appropriation of landscapes as historical documents and is noteworthy for its aesthetic-linguistic dimension when using description with uncommon skill10. Vidal de la Blache's writing has a beautiful poetic imagery that leads the reader through an ancient France characterized by varied places, landscapes, languages, and customs in which the local supplants outside influences. It is a defense of the "France profonde." Since Vidal de la Blache never used the term, there are no pejorative connotations; it serves here as a didactic illustration of French regions' singular history and geography.

The same applies to the Tableau géographique de la France. Its title and descriptive strategy are not accidental: if the Tableau is a painting of France, we should convert its images into landscaped text. As a result, the Tableau is celebrated as one of the main mimesis of France. The work emphasizes her most precious treasures: her land, her soil, her people, and her culture. When reading it, the French from the north and the south recognize themselves and feel integrated into a whole for which they are proud and responsible: their homeland. In the long run, unconsciously, borders, in terms of contact, encounter, solidarity between spaces, and defense, are the relief, forest, and river, but, above all, the French themselves. This is one mimetic way that humankind enters the scene in geography. Needless to say, in an increasingly human geography.

The concept of pays aptly highlights the inextricable link that the French have with the land, as an environment, composed of a range of material elements (soil, climate, plantations, and houses), resulting in a symbolic atmosphere where each place has a unique spirit. France's myriad of pays makes it a different, special country, more diverse than others. The territory's wealth is due to physical elements and natural landscapes, and also how people have adapted precisely to the benefits and vicissitudes of their milieu. In a word, to the genres of life11, heritage, and foundation of French identity. In 1885, Vidal de la Blache criticized "systematic" geography for failing to value popular knowledge and geographical nomenclature because added to direct observation they are essential to "extract the secret of its appearance and influence from the soil" (VIDAL DE LA BLACHE 1885: 173, emphasis added). This secret has several layers: vigorous physical geography favors France thanks to its "general harmony" (VIDAL DE LA BLACHE 1904: 335), driving exchanges and communication.

There is an affluence of natural impulses in French territory, stimulating relationships between men (...) France is a space whose parts are naturally related, whose inhabitants have learned from an early age to attend and know each other. And if they have formed spontaneous relationships amongst themselves, geographical conditions have allowed and caused them (VIDAL DE LA BLACHE 1996-97: 3-4 and 7 [1902]).

From a political point of view, the most famous name in modern French academic geography reinforces the welding of a more privileged and diversified myth: the founding myth of Nature (see CHAUÍ 2000), thus making soil and territory partially accessible to foreigners in a way that does not disturb the harmony between the French and their secularly designed environment. "Crossing social classes, thought reaches and discovers its foundation, its raison d'être: French soil is also a historical character. By the pressure it exerts on habits, by the resources made available to our misfortunes, it regulates the oscillations of our history" (VIDAL DE LA BLACHE 2007: 780-781 [1903]). The myth becomes more notorious when we turn our attention to the threats to French borders in Europe and colonial spaces worldwide, with harmony giving way to imperial conflicts, capitalist competition, and the dispute for hegemony. Neither does the text's vocabulary and tone fit into any romantic, serene, 
tranquil scenario (see, to mention just one, VIDAL DE LA BLACHE 1897a). In short, what applies to France does not necessarily apply to others. Therefore, it seems an examination of any discourse should consider both the place of origin and destination (RIBEIRO 2010).

A little familiarity with the history of geography is sufficient to pose the question of whether there is enough contrast here to consider the geographies developed by Ratzel and Vidal incompatible, as Lucien Febvre and his repeaters have tried to persuade us. Certainly not. Both Ratzel's Boden and the Vidalian Sol are supporting pillars, the driving force of German and French virtues in the last decades of the nineteenth and early twentieth century. In an excerpt that closely resembles Ratzel's reflections, Vidal de la Blanche writes of Northern France, the space where "the French state was formed" (VIDAL DE LA BLACHE 2007: 394 [1903]), as follows: "Like a tree in a forest, a State does not separate itself from the environment where other States live in contact with and in competition with each other" (idem). It is not by chance that such strength, so full of symbolism, is intensely present in the pages of the Tableau, the apex of how France and its identity are tributaries of its territory (VIDAL DE LA BLACHE 2007: 535, 546-547, 780-781, 783 [1903]). Notwithstanding, he notes that demarcating that the soil is more important for the French than for Germans

For Germans, Germany is, above all, an ethnic idea. What the Frenchman distinguishes in France, as his regrets attest when he distances himself from it, is the goodness of the land and the pleasure of living in it. For the French, the land is the pays par excellence, that is, something closely related to the instinctive ideal he has about life (idem, p.384).

Unlike the case of Celts and Anglo-Saxons, Slavs and Germans, in France, there is no antagonism between races (ibidem, p.386). A "beneficial force" prepared the "national existence," a "genius loci (...) that conferred something healthy" (ibid.). Yes, there is diversity in France, but it served to enrich the country and its unity since it did not lead to fragmentation. Furthermore, the founding myth involves dissolving political geography in physical geography; in other words, naturalizing what is human. It complements physical geography (ibid., P.387-389) and its role in shaping French territory. There is "harmony," a word repeated over and over in the Tableau and several articles, and "balance between the parts" (ibid., p.335), that is, physical features bring together and strengthen the bonds between the people and the territory. Thus, in a single movement, Vidal de la Blache takes a political and scientific step formulating ideas of national territory and human geography through the handling of people and the environment, everyday life and landscape, historical process, and nature. Now, in its own way, geography participates in a kind of mimesis. France and the French are transformed in and through the landscape (in the broad sense of integrating the other geographical categories), are confused with it so that, in the end, they become one. That one is nothing other than national unity, partially split after the defeat of 1871 and the Paris Commune.

Inverting the logic of canonization, we would like to point out that specific texts - Des divisions fondamentales du sol français, Routes et chemins de l'Ancienne France and Les pays de France (VIDAL DE LA BLACHE 1888, 1996-97 [1902], 1904), only appear to focus stricto sensu on the human-environment relationship. Deep down, they are subtle yet revealing political speeches whose contents appeal to French people's identity, belonging, and roots in their pays and their regions of origin. The landscape, the land, the environment are a decoy. Likewise, the Tableau should be read as a political geography book (a term used several times in the text) since it addresses topics such as the political formation of the Kingdom of France, borders as spaces of conflict, the importance of occupying main access roads and the ensuing political power, opposition to centralization in Paris in favor of greater regional autonomy, and the identity of the French people, among others ${ }^{12}$.However, for those who persist in a conventional reading (cf. GUIOMAR 1997 [1986]; LÉVY 2003), perhaps it is paradoxical that an essentially descriptive book with a strong content of physical geography concludes with a discussion on Centralization and life in the past, that is to say, an unquestionably political topic.

To conclude in such a way, only corroborates the entire book's leitmotiv. The preceding pages paved the way for the defense of national unity, the potency of the soil, regional, cultural and linguistic diversity, and the territory's solidity. A comprehensive reading of the Tableau requires us to examine the period's political situation, with the construction of national identities based on the homeland, simultaneously a material and transcendental force to amalgamate people, Nature, and State. The choice 
of a descriptive style aims to outline France's image in the light of an interplay between identity and diversity, life in general, and the local scale. The territory itself is the political element, erected as a privileged active stage for the nation, and therefore, something citizens should preserve and defend. It is not by chance that the national question is the keynote of two of his other main books: États et nations de l'Europe autour de la France and La France de l'Est: Lorraine-Alsace (VIDAL DE LA BLACHE 1889, 1994 [1917]).

Finally, Vidal de la Blache based his method on an innovative temporal perspective for his age, which was soon reworked more systematically by the periodical Annales de Géographie's historians. We are referring to the long-term démarche, which privileged permanence over change and structures over events. In our view, which does not involve any infertile corporatism, Marc Bloch, Lucien Febvre, and even Fernand Braudel do not give the geographer due credit for this methodological innovation (RIBEIRO 2017). The passage below seems to clearly announce the program of a history of longue durée that would be enshrined in the Annales and permanently change how history is written and practiced.

What is certain is that it remains and will always remain fixed, something permanent that, through all the changes multiplied more than ever in the current era, represents the perpetuity and permanence of the land's influence. Thus, the question arises: how can one distinguish between the constant and solid that will remain, from what is condemned to disappear or, at least, be transformed? This is where geographic method can shed some light; it illuminates this evolution that, quite rightly, concerns (not without sometimes creating anxiety) the spirits deeply connected to the French soil - with the ideas, memories, and impressions it evokes (VIDAL DE LA BLACHE 1904: 343)

Next, as if anticipating ipsis litteris the Annales's criticisms of Political History with the great names of kings, ministers, and generals, Vidal de la Blache points out that the central factual and epistemological treasure is none other than soil, land, and territory, that together support and provide all French life.

This beautiful and varied soil that was our great strength in the past is rich in teachings. It contains the principle of these restorations and upheavals that have certainly not been lacking in our history. We attribute political figures with the successes and recoveries through which our country has managed to rise after defeats and catastrophes. However, ultimately, the asset in the game played by politicians, which made statesmen's procedures benefit the country was the benevolence of the soil (idem, p.344).

Here, the Vidalian proposal is clear: the history of French territory was built pays by pays, region by region, over the longterm. Consequently, the importance of the soil surpasses revolutions; it is France's material and symbolic cradle.

Economic revolutions, like those of the present, deeply stir the human soul, moving a range of desires and new ambitions. In some, they inspire regrets; in others, fantasies. However, this restlessness should not distract us from the foundation of things. When a blast of wind violently shakes the surface of clear water, everything oscillates and mixes; however, in an instant, the background image reappears. The careful study of what is fixed and permanent in France's geographical conditions must be or must become, more than ever, our guide (VIDAL DE LA BLACHE 2007: 783 [1903]).

\section{CONCLUSION}

Since 1999, when small excerpts from the conclusion and introduction of the Tableau were published in Portuguese by the magazine Geographia (UFF), the last translation of Vidal de la Blache in our language besides As características próprias da geografia in the widely disseminated collection Perspectivas da Geografia Perspectives of Geography during the military regime (CHRISTOFOLETTI 1982), studies of the French geographer have been gaining momentum in Brazil. The notable expansion 
of postgraduate programs, the subsequent internationalization of teachers and students, and the progressive digitalization of foreign journals are instrumental in institutional terms and the circulation of knowledge. Above all, we wish to emphasize the intellectual effects Vidalian ideas have had on different generations.

In his analysis of Wolfgang Iser's reader-response theory, Costa Lima points out that certain novelists' work admit the existence of gaps, which are catalysts for new questions, readings, and filling-ins over generations (COSTA LIMA 2010: 141). Thus, by abdicating from merely copying facts, recognizing that even a map is an interpretation and not a reproduction (VIDAL DE LA BLACHE 1916: 98), and developing writing full of intangible layers, to some extent, Vidal de la Blache suspends the Cartesian-Newtonian strand of modernity and projects his creation beyond his time (1845-1918).

The option to investigate Vidal de la Blache from Brazil in Portuguese and French establishes tension with the French language and tradition and avoids copies, repetitions, and intellectual subservience in the periphery concerning the centers. The distance from the archives, the precarious understanding of an alien historical-social context, and the mistrust felt by some foreign colleagues (still existing, but to a lesser extent) should serve as further stimuli in the search for a "peripheral" interpretation of Vidal de la Blache. After all, if rather than being processed topically, science treats places, institutions, and networks as parts of its procedures and results (LATOUR (2011 [1987]) and "objects" are analyzed from different angles, according to different historical periods, then there is room for the academic study of Vidal de la Blache in the Tropics and a regifting to the world by our best modernist legacy (see SANTORO \& BUARQUE 2018).

Thus, we can conclude that the concept of mimesis reworked by Brazilian literary theorist Luiz Costa Lima has illuminated distinct layers of Vidalian reflection, notably, metamorphosing the environment into categories like landscape, region, and pays to strengthen French territory and national identity on the one hand and to establish methodological bases for the nascent human geography on the other. How physical elements such as climate, relief, and vegetation are inserted in the scientific plane of the innovative géographie humaine and the political-symbolic sphere of belonging to the homeland, with textual descriptions that create perceptual images: this is what we mean by geographic mimesis that goes beyond imitation.

The Vidalian method is not concerned with methodical historiography's grandiose events and characters embodied in kings, ministers, and generals, or official written documents. Instead, he evokes a sui generis artifact: the soil. Although narrower, this approach is by no means less effective. Vidal de la Blache thoroughly describes the entire French territory, including both the great physical features and those on a local scale, and paints a picture anxious not to miss any detail but without falling into objectivist realism. He values peasants and their geographic knowledge and composes the "geographical personality of France" (the title of the first part of the Tableau ), questioning "in what sense [she] is a geographical being" (VIDAL DE LA BLACHE 2007: 328 [1903]). In a situation marked by the "invention of traditions" (HOBSBAWM 1997 [1983]) and "imagined communities" (ANDERSON 1983), he offers the French an image of their own country, amalgamated by forces built in the light of a centuries-long temporality. His countrymen must boast of their achievements, the apex of which are the French territory, French regions, French borders, and French landscapes. Vidal de la Blache describes a world that needed to be known, recognized, and disseminated (mimitized, therefore) not only by and for intellectuals, politicians, and capitalists, but also by ordinary men. A gift of Nature, French soil is also their handiwork; they have shaped abbeys, shops, routes, customs, crops, pays, contrées, and genres de vie. He places his country and countrymen's deepest roots in the territory. In a mixture of materiality and metaphysics, the territory represents an "unshakable" unity, the true north that must never be lost sight of, the guiding thread of a long-lasting story. "(...) without ignoring the inevitable changes brought about by the general march of the world, we should rely on the comforting feeling of the power and virtue of the soil" (VIDAL DE LA BLACHE 1904: 344, emphasis added). He wants to convey that people and Nature live in deep harmony in France, an alliance built over a long time.

Although politically conservative, the methodological scope of Vidalean reasoning implies an essence may be called geographic mimesis, whose vigor is in no way compromised by the dichotomous and superficial interpretations that persist in finding followers. 


\section{ACKNOWLEDGMENT}

This article is part of the research "Center of calculation, circulation networks and history of geography: the case of the Brazilian Journal of Geography of IBGE (1939-1996)" contemplated by the Faperj public notice "Support for Emerging Research Groups in the State of Rio de Janeiro (2019) "under our direction. I am grateful for the generous and careful reading of the anonymous referees of Mercator and of the master in Geography João Alves de Souza Neto.

\section{NOTE}

1- For the Brazilian reader attracted by the history of geography in terms of continuities, it would not be difficult to draw parallels with the "philosophy of techniques" designed by Milton Santos in his effort to renew geography and explain the historical period of globalization at the turn of the twenty-first century. (SANTOS 1996).

2- Two decades later, the intricate nexuses between description and image were problematized with rare insight by the British historical geographer HC Darby in The problem of geographical description (DARBY 1962).

3- Praise here for the breathtaking work done by the geographer and translator Leonardo Arantes.

4- From its pioneering and stimulating phase of 2000 to 2007 and since 2012 , a new theoretical and institutional configuration, the Brasilis Network. Brazilian Network of History of Geography and Historical Geography and its journal Terra Brasilis have played an important role in this process. Available in https://journals.openedition.org/terrabrasilis/.

5- On Bowman's role in US imperialist ambitions since the end of the First World War, consult Neil Smith's dense and revealing research (SMITH 2004).

6- Although ignoring the dialogue with geographers - except for Humboldt, whose scope, however, is not restricted to modern disciplinary limits - Costa Lima's seduction by mimesis led him to examine a work with a strong geographical content: The Sertões by Euclides da Cunha (COSTA LIMA 1997). If there is not enough space to synthesize the richness of his analyzes, let us allude to the historical and stylistic intersections between Cunha's classic and the Tableau de la Géographie de la France, by Vidal de la Blache, published in 1902 and 1903 respectively (CUNHA 2016 [1902]; VIDAL DE LA BLACHE 2007 [1903]).

7- He cites the same authors as the German, such as Humboldt, Ritter, Wagner and Ratzel himself. In a suggestive text, the Canadian geographer Guy Mercier attests that Ratzel and Vidal have the same conception of the human-nature relationship and, consequently, ended up producing very similar conceptions of State and region (MERCIER 2009 [1995]).

8- Most of the references to Vidal de La Blache listed above are available in Portuguese (see HAESBAERT, PEREIRA \& RIBEIRO, 2012).

9- Remodeled in the light of a new conceptual contribution, the following item is an unpublished version in Portuguese of parts of an article published in French (RIBEIRO 2014).

10- How many criticisms has Classical Geography received regarding description, that it is unable to endow Geography with scientificity? Mistaken criticisms that, preferring to emphasize a single element instead of taking the work as a whole, end up diminishing the description. Fortunately, Jean-Marc Besse places it in a very rich tradition linked to landscape painting (BESSE 2000). Anticipating some of the trends assumed years later by Vidalian studies, in 1979 Paul Claval already emphasized the existence of an "intimate connection between Vidal's aesthetics and his conception of the use of space by groups" (CLAVAL 1979: X).

11- Even though the two famous articles on genres of life were only written in 1911, the concept is mentioned in 1903 in Tableau and in 1904 in Les pays de France .

12- In the book Le Tableau de la géographie de la France in the labyrinthe des formes, organizer Marie-Claire Robic thinks the Tableau "represents the paradigm of French national identity, a symbolic representation of the territory that causes a stable and relatively consensual adhesion" (ROBIC, 2000: 8). Among its articles that touch directly on the topics addressed here, please consult the following 
references (PETITIER 2000; OZOUF-MARIGNIER 2000; ROBIC 2000a; OZOUF-MARIGNIER \& ROBIC 2000). The inspiration for re-reading Vidal de la Blache in the light of politics, however, stems from other works (BERDOULAY 1995 [1981]; NICOLAS-OBADIA \& GUANZINI 1987, NICOLAS-OBADIA 1988), especially those by Mercier (MERCIER, 1995, 1998, 2001, 2009).

\section{REFERENCES}

ALPERS, Svetlana. A arte de descrever. São Paulo: Edusp (1999 [1983]). 427p. Trad. Antonio de Paula Danesi.

ANDERSON, Benedict. Imagined Communities. London: Verso (1983). 240pp.

BAKER, Alan. Geography and history. Bridging the divide. Cambridge: Cambridge University Press (2006 [2003]). 279p.

BASSIN, Marc. Friedrich Ratzel (1844-1904). Geographers: Biobibliographical Studies, vol. 11, pp. 123-132 (1987).

BASSIN, Marc. Imperialism and the nation state in Friedrich Ratzel's political geography. Progress in human geography, 11, pp. 473-495 (1987a).

BASSIN, Marc. Race contra space: the conflict between german Geopolitik and National Socialism. Political Geography Quaterly, vol. 6, n.2, april, pp. 115-134 (1987b).

BERDOULAY, Vincent. Des mots et des lieux. La dynamique du discours géographique. Paris: Éditions du CNRS (1988). 108 p.

BERDOULAY, Vincent. La formation de l'école française de géographie (1870-1914), 2e édition. Paris : Éditions du CTHS (1995 [1981]). 253 p.

BERDOULAY, Vincent, SOUBEYRAN, Olivier. Lamarck, Darwin e Vidal: aux fondements naturalistes de la géographie humaine. Annales de Géographie, n.561-562, pp. 617-634 (1991).

BESSE, Jean.-Marc. Voir la Terre: six essais sur le paysage et la géographie. Arles : Actes Sud/ENSP (2000). $161 \mathrm{p}$.

BLUMENBERG, Hans. "Imitação da natureza": contribuição à pré-história da idéia do homem criador. In: COSTA LIMA, Luiz (org.). Mímesis e a reflexão contemporânea. Rio de Janeiro: EDUERJ, pp.87-135 (2010 [1957]). Tradução de Luiz Costa Lima.

BOWMAN, Isaiah. Geography vs. Geopolitics. Geographical Review, Vol. 32, No. 4, Oct., pp. 646-658 (1942).

BRAUDEL, Fernand. Civilização Material, Economia e Capitalismo: séculos XV-XVIII. Volume 1: As Estruturas do Cotidiano. São Paulo: Martins Fontes (1996 [1967]). 535p. Tradução de Telma Costa.

BROTTON, Jerry. A History of the World in Twelve Maps. London: Allen Lane (2012). 544pp.

CARVALHO, Marcos de. Diálogos entre as Ciências Sociais: um legado intelectual de Friedrich Ratzel (1844 - 1904). Biblio 3W. Revista de Geografia y Ciencias Sociales, n. 34 (1997).

CARVALHO, Marcos de. Ratzel: releituras contemporâneas. Uma reabilitação?Biblio 3 W. Revista de Geografia y Ciencias Sociales, n. 25 (1997a).

CHAUÍ, Marilena. Brasil: mito fundador e sociedade autoritária. São Paulo: Perseu Abramo (2000). $103 p$.

CHRISTOFOLETTI, Antonio (org.) Perspectivas da Geografia. São Paulo: Difel (1982). 156p.

CLAVAL, Paul. Géographies et géographes. Paris: L'Harmattan (2007).

CLAVAL, Paul. A contribuição francesa ao desenvolvimento da abordagem cultural na Geografia. In:

CORREAA, Roberto Lobato, ROSENDHAL, Zeny (orgs.). Introdução à Geografia Cultural. Rio de 
Janeiro: Bertrand Brasil, pp.147-166 (2003). Sem indicação de tradutor.

CLAVAL, Paul. Préface. In: VIDAL DE LA BLACHE, Paul. Tableau de la géographie de la France. Paris: Taillandier, p. 1-23 (1979).

COSGROVE, Denis. Apollo's eye: a cartographic genealogy of the earth in the Western imagination. Baltimore: Johns Hopkins University Press (2003). 352 p.

COSTA LIMA, Luiz. O insistente inacabado. Recife: Cepe (2018). 248p.

COSTA LIMA, Luiz. Luiz Costa Lima: uma obra em questão. Organização de Dau Bastos. Rio de Janeiro: Garamond/FAPERJ (2010). 406p.

COSTA LIMA, Luiz. História. Ficção. Literatura. São Paulo: Cia. das Letras (2006). 440p.

COSTA LIMA, Luiz. Mímesis: desafio ao pensamento. Rio de Janeiro: Civilização Brasileira (2000). $431 \mathrm{pp}$.

COSTA LIMA, Luiz. Terra Ignota. A construção de Os sertões. Rio de Janeiro: Civilização Brasileira (1997). 304p.

COWEN, Deborah, Smith, Neil. After Geopolitics? From the Geopolitical Social to Geoeconomics. Antipode 40: 2-48 (2009).

CUNHA, Euclides da. Os Sertões. Campanha de Canudos. Edição crítica e organização de Walnice Nogueira Galvão. São Paulo: Ubu/Edições Sesc (2016 [1902]). 700p.

DARBY, Henri Clifford. The problem of geographical description. Transactions of the Institute of British Geographers, 30, pp.1-14 (1962). Versão em português: O problema da descrição geográfica. Confins 44, pp.1-15 (2020). Tradução de Guilherme Ribeiro e João Alves de Souza Neto.

DAVIES, Archie. Josué de Castro's Geografia Combatente and the political ecology of hunger.PhD in Geography at King's College London, april (2019). 306p.

DEMANGEON, Albert. Géographie politique, à propos de l'Allemagne. Annales de Géographie, n. 272, pp.113-119 (1939).

DEMANGEON, Albert. Géographie politique. Annales de Géographie, n. 229, pp.22-31 (1932).

FEBVRE, Lucien. La Terre et l'évolution humaine. Introduction géographique à l'histoire. Paris : La Renaissance du Livre (1922). 471pp.

FERRETTI, Federico. History and philosophy of geography I: Decolonising the discipline, diversifying archives and historicising radicalism. Progress in Human Geography, vol. 44, issue 6, pp. 1161-1171 (2019).

FOUCAULT, Michel. L'ordre du discours. Paris: Gallimard (1971 [1970]). 88pp.

GÓMEZ MENDOZA, Josefina. Geografía e Historia : encuentros e desencuentros en Francia y en España a lo largo del siglo XX. Geographia (UFF), n.20, pp.7-52 (2008 [2007]).

GRATALOUP, Christian. L'invention des continents. Comment l'Europe a découpéle monde. Paris: Larousse (2009). 224 p.

GUIOMAR, Jean.-Yves. Le Tableau de la géographie de la France de Vidal de la Blache. In:NORA, Pierre. (dir.), Les Lieux de Mémoire. I. La République. La Nation. Les France, Paris, Gallimard, p. 1073-1098 (1997 [1986]).

HAESBAERT, Rogério, RIBEIRO, Guilherme, PEREIRA, Sergio (orgs.). Vidal, Vidais. Textos de Geografia Humana, Regional e Política. Rio de Janeiro: Bertrand Brasil (2012). 464p.

HOBSBAWM, Eric J. The Age of Empire, 1875-1914. London: Weidenfeld and Nicolson (1987). 404pp. 
HOBSBAWM, Eric J. A invenção das tradições. In: HOBSBAWM, Eric J., RANGER, Terence (orgs.).A invenção das tradições. Rio de Janeiro: Paz e Terra, pp.9-23 (1997 [1983]). Tradução de Celina Cardim Cavalcante.

HOLDAR, Sven. The ideal state and the power of geography. The life-work of Rudolf Kjellén. Political geography, vol.11, n.3, may, pp.307-232 (1992).

HUMBOLDT, Alexander von. Considerações introdutórias sobre as diversas formas de apreciar a natureza e uma investigação científica de suas leis. Geographia (UFF), n.27, pp.129-150 (2012 [1827-1828]). Tradução de Fabrício Coelho.

KEIGHREN, Innes M., ABRAHAMSSON, Christian, DELLA DORA, Veronica. On canonical geographies. Dialogues in Human Geography, vol 2, 3, pp.296-312 (2012).

LACOSTE, Yves. A geografia - isso serve, em primeiro lugar, para fazer a guerra. $3^{\text {a }}$ ed. Campinas: Papirus (1988 [1976]). 154p.

LATOUR, Bruno. Ciência em ação. Como seguir cientistas e engenheiros sociedade afora. $2^{\mathrm{a}}$ ed. São Paulo: Editora Unesp (2011 [1987]). 404p. Tradução de Ivone C. Benedetti

LEPENIES, Wolf. As três culturas. São Paulo: Edusp (1996 [1985]). 392p. Tradução: Maria Clara Cescato.

LÉVY, Jacques. Vidal de la Blache, Paul. In: LEVY, Jacques, LUSSAULT, Michel (dir.). Dictionnaire de la géographie et de l'espace des sociétés. Paris: Belin, p. 984-987 (2003).

MACKINDER, Halford John. O mundo redondo e a vitória da paz. Boletim Geográfico, vol. 12, n.118, pp.80-84 (1954 [1943]). Tradução de Lidnéa Barata Bessadas.

MACKINDER, Halford John. Geography, an art and a philosophy. Geographical Association, vol. 27, n.4, December, pp.122-130 (1942).

MACKINDER, Halford John. O ensino de geografia sob a ótica imperial e os usos que podem e devem ser feitos da instrução visual. Geographia (UFF), n.31, pp.142-152 (2004 [1911]). Tradução de Guilherme Ribeiro e Leroy Honório Azevedo.

MACKINDER, Halford John. The geographical pivot of history. The Geographical Journal, Vol. 23, No. 4, Apr., pp. 421-437 (1904).

MARTIN, Geoffrey J. All possible worlds. A history of geographical ideas. Fourth Edition. Newy York/Oxford: Oxford University Press (2005 [1972]). 605p.

MARTINS, Luciana. Friedrich Ratzel. Geografia (UFF), n.5, pp.89-91 (2001).

MELGAÇO, Lucas. Thinking Outside the Bubble of the Global North: Introducing Milton Santos and "The Active Role of Geography". Antipode, 49 (4), pp.1-6 (2017).

MERCIER, Guy. La géographie de Paul Vidal de la Blache face au litige guyanais : la science à l'épreuve de la justice. Annales de Géographie, n. 667, pp.294-317 (2009).

MERCIER, Guy. Entre science et patrie. Lecture du régionalisme de Paul Vidal de la Blache. Cahiers de Géographie du Québec, vol. 45, n.126, déc., pp.389-412 (2001).

MERCIER, Guy. Paul Vidal de la Blache ou la légitimation patriotique de la région et de la géographie. Revue française de géoéconomie, n. 5, printemps, pp. 137-146 (1998).

MERCIER, Guy. A região e o Estado segundo Friedrich Ratzel e Paul Vidal de la Blache. Geographia (UFF), n.22, pp.7-36 (2009 [1995]). Tradução de Guilherme Ribeiro.

MEZZADRA, Sandro, NEILSON, Brett. Border as method, or, the multiplication of labor. Durhan and London: Duke University Press (2013). 358pp.

MIGNOLO, Walter. Reflections on translation across colonial epistemic differences. Languages, media and visual imaginary. In: ITALIANO, Federico, RÖSSNER, Michael (edited by). Translatio/n: 
Narration, Media and the Staging of Differences. Bielefeld: Transcript Verlag, pp.19-34 (2012).

MIGNOLO, Walter. Epistemic Disobedience, Independent Thought and Decolonial Freedom. Theory, Culture \& Society, Vol. 26 (7-8): 1-23 (2009).

MIGNOLO, Walter. The idea of Latin America. London: Blackwell (2005). 218pp.

MIGNOLO, Walter. Histórias Locais/Projetos Globais: Colonialidade, Pensamento Liminar e Saberes Subalternos. Belo Horizonte: Editora da UFMG (2003 [2000]). Tradução de Solange Ribeiro de Oliveira. 505p.

NICOLAS-OBADIA, Georges. Paul Vidal de la Blache et la politique. Bulletin de l'association géographique française, 4, pp.333-337 (1988).

NICOLAS-OBADIA, Georges, GUANZINI, Catherine. Géographie et Politique: Paul Vidal de la Blache. Série Espace, science et géographie, n.1. Lausanne: Erastosthène-Méridien (1987). 80p.

Ó TUATHAIL, Gearóid. Thinking critically about geopolitics. In: Ó TUATHAIL, Gearóid, DALBY, Simon, ROUTLEDGE, Paul. (ed.). The geopolitics reader. London and New York: Routledge, pp.1-12 (1998).

Ó TUATHAIL, Gearóid. Critical geopolitics. The politics of writing global space. London: Routledge (1996). 250p.

OZOUF-MARIGNIER, Marie-Vic. Le Tableau et la division régionale: de la tradition à la modernité. In: ROBIC, Marie-Claire (dir.). Le Tableau de la Géographie de la France de Paul Vidal de la Blache. Dans le labyrinthe des formes. Paris: Éditions du CTHS, pp.153-181 (2000).

PETITIER, Paule. D'un tableau l'autre. Le Tableau de la France de Michelet et le Tableau de la géographie de la France de Vidal de la Blache. In: ROBIC, Marie-Claire (dir.). Le Tableau de la Géographie de la France de Paul Vidal de la Blache. Dans le labyrinthe des formes. Paris: Éditions du CTHS, pp.128-150 (2000).

PRED, Alan. From here and now to there and then: some notes on diffusions, defusions and disillusions. In: BILLINGE, Mark, GREGORY, Derek, MARTIN, Ron (edited by). Recollections of a revolution. Geography as a spatial science. London: Macmillan, pp. 86-103 (1984).

RAFFESTIN, Claude, LOPRENO, Dario, PASTEUR, Yvan. Géopolitique et histoire. Lausanne: Payot (1995). 330p.

RATZEL, Friedrich. Sobre a interpretação da natureza. Geographia (UFF), n.23, pp.157-176 (2010 [1904]). Tradução de Marcos B. de Carvalho, a partir de esboço parcial feito por Mara Sandra Zanin. Revisão Técnica: Wolf Dietrich-Sahr.

RATZEL, Friedrich. O espaço da vida: um estudo biogeográfico. Geographia (UFF), n.45, 46 e 47, pp. 107-116, 120-130 e 115-129 (2019 [1901]). Tradução de Leonardo Arantes.

RATZEL, Friedrich. Geografia dell'uomo (Antropogeografia). Principî d'applicazione dela scienza geografica alla storia. Milano: Fratelli Bocca Editori (1914 [1899]). 596p. Traduzione Ugo Cavallero.

RATZEL, Friedrich. Géographie politique. Paris: Economica (1988 [1897]). 385pp. Traduction de Pierre Rusch.

RHEIN, Catherine. La Géographie, discipline scolaire et/ou science sociale? (1860-1920). Revue française de Sociologie, XXIII, pp.223-251 (1982).

RIBEIRO, Guilherme. Fernand Braudel, geo-história e longa duração: críticas e virtudes de um projeto historiográfico. São Paulo: Annablume (2017). 211p.

RIBEIRO, Guilherme. Geografia, fronteira do mundo. Ensaio sobre política, epistemologia e história da geografia. Geographia (UFF), v. 17, p. $39-73$ (2015).

RIBEIRO, Guilherme. Question régionale, identité nationale et émergence du monde urbain-industriel. 
La modernité dans l'œuvre de Paul Vidal de la Blache. Annales de Géographie, v. 699, p. 1215-1238 (2014).

RIBEIRO, Guilherme, HAESBAERT, Rogério, PEREIRA, Sergio Nunes. Relendo Vidal: em busca de novos enfoques. In: HAESBAERT, Rogério, PEREIRA, Sergio Nunes, RIBEIRO, Guilherme (orgs.). Vidal, Vidais: textos de Geografia Humana, Regional e Política. Rio de Janeiro: Bertrand Brasil, p. 13-19 (2012).

RIBEIRO, Guilherme. Território, império e nação: a geopolítica em Paul Vidal de la Blache. Revista da Anpege, n.6, p. 29-42 (2010).

RIBEIRO, Guilherme. Para ler Geografia ou A Geografia segundo Lucien Febvre. Terra Livre, n.32, pp.121-136 (2009).

ROBIC, Marie-Claire. Introduction. In: ROBIC, Marie-Claire (dir.). Le Tableau de la géographie de la France de Paul Vidal de la Blache. Dans le labyrinthe des formes. Paris: Éditions du CTHS, pp.7-17 (2000)

ROBIC, Marie-Claire. Territorialiser la nation. Le "Tableau" entre géographie historique, géographie politique, géographie humaine. In: ROBIC, Marie-Claire (dir.). Le Tableau de la géographie de la France de Paul Vidal de la Blache. Dans le labyrinthe des formes. Paris: Éditions du CTHS, pp.184-225 (2000a).

ROBIC, Marie-Claire. Éloge de la circulation. Strates. Crises et mutations des territoires, n. 9, pp.1-10 (1996-97).

ROBIC, Marie-Claire. A criação dos Annales de Géographie (1891). Estratégia universitária e geografia humana. Continentes. Revista de Geografia do Departamento de Geociências da UFRRJ, n. 3, jul.-dez (2013 [1993]). Tradução de Guilherme Ribeiro e Lara D’Assunção dos Santos.

ROBIC, Marie-Claire, OZOUF-MARIGNIER, Marie-Vic. Un Tableau à vif... La réception du Tableaude la géographie de la France de P. Vidal de la Blache. In: ROBIC, Marie-Claire (dir.). Le Tableau de la Géographie de la France de Paul Vidal de la Blache. Dans le labyrinthe des formes. Paris: Éditions du CTHS, pp.252-270 (2000).

SANTORO, Fernando, BUARQUE Luisa Prefácio da edição brasileira. In: CASSIN, Barbara. Dicionário dos intraduzíveis: um vocabulário das filosofias. Volume Um: Línguas. Organização de Fernando Santoro e Luisa Buarque. Belo Horizonte: Autêntica, pp.5-15 (2018).

SANTOS, Milton. A natureza do espaço. Técnica e tempo. Razão e emoção. São Paulo: Hucitec (1996). $245 \mathrm{p}$.

SCHMITT, Carl. O nomos da Terra no direito das gentes do jus publicum europaeum. Rio de Janeiro: Contraponto/Editora PUC-Rio (2014 [1950]). 352p. Tradução: Alexandre Franco de Sá, Bernardo Ferreira, José Maria Arruda e Pedro Hermílio Villas Bôas Castelo Branco.

SMITH, Neil. American Empire. Roosevelt's geographer and the prelude to globalization. Berkeley/Los Angeles/London: University of California Press (2004). 557p.

SMITH, Woodruff D. Politics and the science of culture in Germany (1840-1920). New York/Oxford: Oxford University Press (1991). 298p.

SOUBEYRAN, Olivier. Imaginaire, science et discipline. Paris: L'Harmattan (1997). 482 p.

VIDAL DE LA BLACHE, Paul. Princípios de Geografia Humana. Lisboa: Cosmos (1954 [1921]). 390p.

VIDAL DE LA BLACHE, Paul. La France de l'est (Lorraine-Alsace). Paris: La Découverte (1994 [1917]). 285p.

VIDAL DE LA BLACHE, Paul. La rénovation de la vie régionale. Foi et Vie, Les questions du temps présent, Cahier B, n.9, mai, p. 103-110 (1917). 
VIDAL DE LA BLACHE, Paul. Evolution de la population en Alsace-Lorraine et dans les départements limitrophes. Annales de Géographie, année XXV, n.134, pp. 97-115 (1916).

VIDAL DE LA BLACHE, Paul. Des caractères distinctifs de la géographie. Annales de Géographie, année XXII, n.124, pp. 289-299 (1913).

VIDAL DE LA BLACHE, Paul. Les chemins de fer en Amérique. France-Amérique, février, p. 69-78 (1912).

VIDAL DE LA BLACHE, Paul. Les genres de vie dans la géographie humaine. Second article. Annales de Géographie, année XX, n॰111, pp.289-304 (1911c).

VIDAL DE LA BLACHE, Paul. Les genres de vie dans la géographie humaine. Premier article. Annales de Géographie, année XX, n 111, pp.193-212 (1911b).

VIDAL DE LA BLACHE, Paul. La conquête du Sahara d'après E. F. Gautier. Annales de Géographie, année XX, n. 109, pp.73-77 (1911a).

VIDAL DE LA BLACHE, Paul. La relativité des divisions régionales, Athéna, Conférence à l'École de hautes études sociales, p. 1-14 (1911).

VIDAL DE LA BLACHE, Paul. La carte internationale du monde au milionième. Annales de Géographie, année XIX, n. 103 (1910a).

VIDAL DE LA BLACHE, Paul. Régions françaises. Revue de Paris, décembre, pp.821-849 (1910).

VIDAL DE LA BLACHE, Paul. A travers l'Amérique du Nord. Revue de Paris, avril, p. 513-532 (1905).

VIDAL DE LA BLACHE, Paul. Les pays de France. La Réforme sociale, vol. 48, p. 333-344 (1904).

VIDAL DE LA BLACHE, Paul. La géographie humaine. Ses rapports avec la géographie de la vie. Revue de Synthèse Historique, 7, août-décembre, pp.219-240 (1903).

VIDAL DE LA BLACHE, Paul. La France. Tableau géographique. In: RIOUX, J.-P. Tableaux de la France. Michelet, Duruy, Vidal de la Blache et Bruno, Paris, Omnibus, p. $327-783$ (2007 [1903]).

VIDAL DE LA BLACHE, Paul. Routes et chemins de l'ancienne France. Strates. Crises et mutations des territoires, n. 9, pp.1-9 (1996-97 [1902]).

VIDAL DE LA BLACHE, Paul. L'éducation des indigènes. Revue Scientifique (Revue Rose), n. 12, tome VII, 20 mars, pp. 353-360 (1897a). Versão em português: A educação dos nativos. Terra Brasilis 11, pp.1-13 (2019). Tradução de Guilherme Ribeiro.

VIDAL DE LA BLACHE, Paul. La zone frontière de l'Algérie et du Maroc, d'après de nouveaux documents. Annales de Géographie, année VI, n. 28, pp. 357-363 (1897).

VIDAL DE LA BLACHE, Paul. États et nations de l'Europe. Autour de la France, Paris, Delagrave (1889). 567p.

VIDAL DE LA BLACHE, Paul. Des divisions fondamentales du sol français. Bulletin littéraire, vol. 2, n. 1, p. 1-7 (1888).

VIDAL DE LA BLACHE, Paul. De quelques réformes dans la terminologie géographique de la France. Revue de géographie, 2, p. 169-173 (1885).

WULF, Andrea. A invenção da natureza: a vida e as descobertas de Alexander von Humboldt. São Paulo: Planeta (2016 [2015]). 587p. Tradução: Renato Marques. 